\title{
INDEKS KEPUASAN MASYARAKAT DALAM \\ PELAYANAN PUBLIK PADA DINAS KEPENDUDUKAN DAN CATATAN SIPIL KABUPATEN CIREBON
}

\author{
Subhan Haris \\ Dosen Universitas Muhammadiyah Cirebon \\ Email:subhan@umc.ac.id
}

\begin{abstract}
ABSTRAK
Salah satu indikator untuk mengukur keberhasilan organisasi publik yang memberikan pelayanan terhadap masyarakat adalah kepuasan masyarakat. Tentu saja masalah yang timbul dapat dilihat dari keluhan-keluhan yang dirasakan oleh masyarakat penerima layanan. Tujuan dari penelitian ini untuk mengetahui: indeks kepuasan masyarakat terhadap pelayanan publik pada Dinas Kependudukan dan Catatan Sipil Kabupaten Cirebon dan faktor-faktor yang berpengaruh terhadap tingkat kepuasan masyarakat di Disdukcapil Kabupaten Cirebon. Jenis penelitian yang digunakan yaitu penelitian deskriptif, sebuah kajian yang dilakukan untuk memperoleh deskripsi/gambaran tentang pelaksanaan pelayanan.
\end{abstract}

Kata Kunci: Pelayanan Publik, Indeks Kepuasan, Disdukcapil

\section{ABSTRACT}

One indicator to measure the success of public organizations that provide services to the community is community satisfaction. Of course the problems that arise can be seen from the complaints felt by the recipient community. The purpose of this study was to find out: the index of community satisfaction with public services at the Cirebon Regency Population and Civil Registry Service and the factors that influence the level of community satisfaction at Disdukcapil Cirebon District. The type of research used is descriptive research, a study conducted to obtain a description/description of the implementation of service.

Keywords: Public Service, Satisfaction Index, Disdukcapil 


\section{PENDAHULUAN}

Berdasarkan data Badan Pusat Statistik Kabupaten Cirebon, jumlah penduduk Kabupaten Cirebon pada tahun 2015 tercatat berjumlah 2.126.178 jiwa. Dari Jumlah tersebut 976.220 jiwa merupakan penduduk berusia antara 2565 tahun. Kecamatan dengan jumlah penduduk paling banyak adalah Kecamatan Sumber yakni 85.930 jiwa. Sedangkan Kecamatan paling rendah jumlah penduduknya adalah Kecamatan Karangwareng yakni 30.036 jiwa. Komposisi penduduk berdasarkan jenis kelamin yakni 1.089.692 berjenis kelamin laki-laki dan $\quad 1.036 .486$ perempuan. Adapun laju pertumbuhan penduduk di Kabupaten Cirebon adalah $1,3 \%$ per tahun.

Disandingkan dengan jumlah penduduk di wilayah III Cirebon (Ciayumajakuning), Kabupaten Cirebon merupakan daerah dengan jumlah penduduk paling banyak. Sedangkan jika disandingkan dengan daerah-daerah yang ada di Jawa Barat jumlah penduduk Kabupaten Cirebon menempati posisi sembilan (BPS Provinsi Jawa Barat, 2017). Presentase penduduk Kabupaten Cirebon dalam provinsi Jawa barat adalah 5\%. Artinya penduduk Jawa Barat 5\% nya tinggal di Jawa Barat.
Data mengenai jumlah penduduk merupakan informasi penting khususnya bagi pemerintah. Data ini memiliki peran strategis dalam membuat rumusan kebijakan dalam pembangunan. Kebijakan tersebut meliputi aspek penentuan alokasi anggaran pembangunan dan penerima manfaat program-program pembangunan serta kebijakan pelayanan publik. Berdasarkan UU No. 25 Tahun 2009 tentang Pelayanan Publik, bahwa pelayanan publik adalah kegiatan atau rangkaian kegiatan dalam rangka pemenuhan kebutuhan pelayanan sesuai dengan peraturan perundang-undangan bagi setiap warga negara dan penduduk atas barang, jasa, dan/atau pelayanan administratif yang disediakan oleh penyelenggara pelayanan publik.

Ruang lingkup pelayanan publik meliputi pelayanan barang publik dan jasa publik serta pelayanan administratif yang diatur dalam peraturan perundangundangan. (UU No. 25 Tahun 2009 tentang Pelayanan Publik). Salah satu bentuk pelayanan administratif adalah administrasi kependudukan. Berdasarkan Peraturan Presiden Republik Indonesia Nomor 25 Tahun 2008 tentang Persyaratan dan Tata Cara Pendaftaran Penduduk dan PenPencatatan Sipil, 
menyatakan bahwa administrasi kependudukan adalah rangkaian kegiatan penataan dan penertiban dokumen dan data kependudukan melalui pendaftaran penduduk, Pencatatan Sipil, pengelolaan informasi administrasi kependudukan serta pendayagunaan hasilnya untuk pelayanan publik dan pembangunan sektor lain. Sedangkan bentuk pelayanan publik pertama adalah pendaftaran penduduk yang meliputi: pencatatan dan penerbitan biodata penduduk, kartu keluarga dan kartu tanda penduduk. Kedua, peristiwa kependudukan yang meliputi: pendaftaran pindah datang penduduk warga negara indonesia dalam wilayah negara kesatuan Republik Indonesia.

Tentunya dalam memberikan pelayanan administrasi kependudukan pemerintah harus memberikan pelayanan yang prima. Pelayanan prima ini tentunya merujuk pada asas-asas pelayanan termaktub dalam UU No. 25 Tahun 2009 tentang Pelayanan Publik diantaranya adalah kecepatan, kemudahan, dan keterjangkauan. Dalam konteks Kabupaten Cirebon, pelayanan administrasi kependudukan masih terpusat di Ibu Kota Kabupaten yakni di Sumber melalui Dinas Kependudukan dan Pencatatan Sipil. Tentunya keadaan ini berimbas kepada kualitas layanan.

Untuk melihat apakah pelayanan publik yang dilaksanakan oleh Dinas Kependudukan dan Catatan Sipil (Disdukcapil) Kabupaten Cirebon telah dilaksanakan secara baik dapat dilihat dari indicator kepuasan masyarakat terhadap layanan tersebut. Indikator kepuasan masyarakat untuk layanan yang diberikan oleh instansi pemerintah berpedoman pada Indeks Kepuasan Masyarakat (IKM) berdasarkan pada Keputusan Menteri Negara Pendayagunaan aparatur Negara Nomor Kep/25/M.PAN/2/2004 tentang pedoman Umum Penyusunan Indeks Kepuasan Masyarakat. Dalam keputusan Menpan tersebut terdapat 14 indikator untuk mengukur Kepuasan Masyarakat yaitu: prosedur pelayanan, persyaratan pelayanan, kejelasan petugas pelayanan, kedidiplinan petugas pelayanan, tanggung jawab petugas pelayanan, kemmampuan petugas pelayanan, kecepatan pelayanan, keadilan dalam mendapatkan pelayanan, kesopanan dan keramahan petugas, kewajaran biaya pelayanan, kepastian biaya pelayanan, kepastian jadwal pelayanan, kenyamanan lingkungan, dan keamanan pelayanan. 
Hingga saat ini masih terdapat keluhan dari masyarakat berkaitan dengan layanan yang diberikan oleh Disdukcapil Kabupaten Cirebon. Keluhan dari masyarakat ini menjadi pemicu pihak Dinas untuk meningkatkan kinerjanya menjadi lebih baik. Kecepatan, kemudahan, keramahan dan keterjangkauan dari petughas selalu diharapkan oleh masyarakat. Hal yang sering dikeluhkan oleh masyarakat yaitu lamanya pelayanan dan aspek jarak yang terlau jauh merupakan keluhan yang dirasakan oleh masyarakat pengguna layanan jasa pada Disdukcapil Kabupaten Cirebon.

Studi ini bertujuan: (1) untuk mengetahui Indeks Kepuasan Masyarakat pelayanan publik pada Dinas Kependudukan dan Catatan Sipil Kabupaten Cirebon dan (2) untuk mengetahui faktor-faktor yang berpengaruh terhadap tingkat kepuasan masyarakat di Disdukcapil Kabupaten Cirebon.

\section{LANDASAN TEORETIS}

Dalam kajian manajemen kualitas atau mutu menurut merupakan suatu kondisi dinamis yang berhubungan dengan produk, jasa, manusia, proses, dan lingkungan yang memenuhi atau melebihi harapan (Goetsh dan Davis 1994). Kualitas meliputi setiap aspek dari suatu perusahaan dan sesungguhnya merupakan suatu pengalaman emosional bagi pelanggan. Menurut Goetsh dan Davis (dalam Tjiptono, 2002) Kualitas adalah suatu kondisi dinamis yang berhubungan dengan produk, jasa, manusia, proses, dan lingkungan yang memenuhi atau melebihi harapan.

Selanjutnya menurut Kotler (2004) kualitas pelayanan merupakan bentuk penilaian konsumen terhadap tingkat pelayanan yang diterima (perceived service) dengan tingkat pelayanan yang diharapkan (expected sevice). Apabila pelayanan yang diterima atau yang dirasakan sesuai dengan yang diharapkan maka kualitas pelayanan dipersepsikan baik dan memuaskan. Menurut Wyckop (dalam Tjiptono, 2000), Kualitas pelayanan adalah tingkat kesempurnaan yang diharapkan dan pengendalian atas kesempurnaan tersebut untuk memenuhi keinginan pelanggan.

Menurut Parasuraman (dalam Tjiptono, 2000) ada dua faktor utama yang mempengaruhi kualitas jasa yang diharapkan (expected service) dan jasa yang dipersepsikan (perceived service). Dalam artikel Parasuraman, dkk 1985 (dalam Tjiptono, 2012) bahwa terdapat 
10 (sepuluh) dimensi pokok kualitas pelayanan sebagai berikut:

1. Reliability, mencakup dua hal pokok, yaitu konsistensi kerja (performance) dan kemampuan untuk dipercaya (dependability). Hal ini berarti organisasi jasa kesehatan memberikan jasanya secara terpat semenjak saat pertama (right the first time). Selain itu juga memenuhi janjinya, misalnya menyampaikan jasanya sesuai dengan jadwal yang disepakati.

2. Responsiveness, yaitu kemauan atau kesiapan para karayawan untuk memberikan jasa yang dibutuhkan pelanggan.

3. Competence, artinya setiap orang dalam suatu organisasi kesehatan memiliki keterampilan dan pengetahuan yang dibutuhkan agar dapat memberikan jasa tertentu.

4. Access, meliputi kemudahan untuk dihubungkan dan ditemui. Hal ini berarti lokasi fasilitas jasa yang mudah dijangkau, waktu menunggu yang tidak terlalu lama, saluran komunikasi organisasi mudah dihubungi, dan lainlain.

5. Kesopanan (courtesy), meliputi sikap santun, respek, atensi dan keramahan para karyawan.
6. Komunikasi, artinya penyampaian informasi kepada para pelanggan dalam bahasa yang mudah dipahami, masalah yang mungkin timbul.

7. Kredibilitas, yaitu sifat jujur dan dapat dipercaya Kredibilitas mencangkup nama perusahaan, reputasi perusahaan, karakter pribadi karyawan dan interaksi dengan pelanggan.

8. Keamanan (Security), yaitu bebas dari bahaya, resiko atau keragu-raguan termasuk di dalamnya adalah keamanan secara fisik (physical safety), keamanan financial (finalcial security), privasi dan kerahasiaan (confidentiality)

9. Kemampuan memahami pelanggan, yaitu berupa memahami pelanggan dan kebutuhan spesifik mereka, memberikan perhatian individual, dan mengenal pelanggan regular.

10. Bukti fisik (Tangibles), meliputi penampilan fasilitas fisik, peralatan, personil, dan bahan-bahan komunikasi perusahaan.

Sedangkan indikator-indikator yang dipergunakan sebagai pedoman dalam penelitian ini mengacu pada Kepmenpan Nomor: KEP/25/M.PAN/2004, tentang pedoman Umum Penyusunan Indeks Kepuasan Masyarakat. Dalam keputusan 
Menpan tersebut terdapat 14 indikator untuk menukur Kepuasan Masyarakat yaitu:

1. Prosedur pelayanan, yaitu kemudahan tahapan pelayanan yang diberikankepada masyarakat dilihat dari sisi kesederhanaan alur pelayanan.

2. Persyaratan pelayanan, yaitu persyaratan teknis dan administratif yang diperlukan untuk mendapatkan pelayanan sesuai dengan jenis pelayanannya.

3. Kejelasan petugas pelayanan, yaitu keberadaan dan kepastian petugas yang memberikan pelayanan (nama, jabatan, serta kewenangan dan tanggung jawab).

4. Kedisiplinan petugas pelayanan, yaitu kesungguhan petugas dalam memberikan pelayanan terutama terhadap konsistensi waktu kerja sesuai ketentuan yang berlaku.

5. Tanggung jawab petugas pelayanan yaitu kejelasan wewenang dan tanggung jawab dalam penyelenggaraan dan penyelesaian pelayanan.

6. Kemampuan petugas pelayanan, yaitu tingkat keahlian dan keterampilan yang dimiliki petugas dalam memberikan/menyelesaikan pelayanan kepada masyarakat.

7. Kecepatan pelayanan, yaitu target waktu pelayanan dapat diselesaikan dalam waktu yang telah ditentukan oleh unit penyelenggara pelayanan.

8. Keadilan dan mendapatkan pelayanan, yaitu pelaksanaan pelayanan dengan tidak membedakan golongan/status masyarakat yang dilayani.

9. Kesopanan dan keramahan petugas, yaitu sikap dan perilaku petugas dalam memberikan pelayanan kepada masyarakat secara sopan dan ramah serta saling menghargai dan menghormati.

10. Kewajaran biaya pelayanan, yaitu keterjangkauan masyarakat terhadap besarnya biaya yang ditetapkan oleh unit pelayanan.

11. Kepastian biaya pelayanan, yaitu kesesuaian antara biaya yang dibayarkan dengan biaya yang telah ditetapkan

12. Kepastian jadwal pelayanan, yaitu pelaksanaan waktu pelayanan, sesuai dengan ketentuan yang telah ditetapkan.

13. Kenyamanan lingkungan, yaitu kondisi sarana dan prasarana pelayanan yang bersih, rapi dan 
teratur sehingga dapat memberikan rasa nyaman kepada penerima pelayanan.

14. Keamanan pelayanan, yaitu terjaminnnya tingkat keamanan lingkungan unit penyelenggara pelayanan ataupun sarana yang digunakan, sehingga masyarakat merasa tenang untuk mendapatkan pelayanan terhadap resiko-resiko yang diakibatkan dari pelaksanaan pelayanan.

\section{METODOLOGI PENELITIAN}

Jenis penelitian yang digunakan dalam melakukan kajian ini menggunakan penelitian deskriptif yaitu sebuah kajian yang dilakukan untuk memperoleh deskripsi gambaran tentang pelaksanaan pelayanan. Populasi dalam kegiatan kajian ini adalah seluruh masyarakat di wilayah Kabupaten Cirebon yang merasakan dan memanfaatkan pelayanan Disdukcapil Kabupaten Cirebon.
Sampel yang digunakan dalam penelitian ini menggunakan multistage sampling, dimana sampel yang diambil dalam penelitian ini dilakukan dengan beberapa tahapan (1), Pengambilan sampel dengan proporsional random sampling, yaitu pengambilan sampel dengan cara diacak proporsional dari populasi dengan mengelompokan berdasarkan pemanfaatan pelayanan (KTP, Kartu Keluarga dan beberapa layanan lainya), kemudian mendistribusikan jumlah sampel secara proporsional terhadap masing-masing pelayanan tersebut (Arikunto, 2006). (2) Langkah selanjutnya adalah mendistribusikan sampel dengan metode Proporsional sampling dengan melihat beberapa kondisi, meliputi wilayah, jumlah penduduk dan jarak wilayah dengan pusat pelayanan kependudukan. (3) Untuk memenuhi akurasi hasil kajian terhadap hasil pelayanan yang dilakukan oleh dinas kependudukan catatan sipil maka minimal 150 responden. 
Nilal indeks kepuasan dihitung dengan menggunakan "nilai rata-rata tertimbang" masing-masing unsur variabel. Dalam penghitungan indeks kepuasan terhadap pelayanan yang diberikan yang dikaji, setiap unsur layanan memiliki penimbang yang sama dengan rumus sebagai berikut:

$$
\text { Bobot nilai rata-rata tertimbang }=\frac{\text { Jumlah Bobot }}{\text { Jumlah Unsur }}
$$

Untuk memperoleh nilai IKK digunakan pendekatan nilai rata-rata tertimbang dengan rumus sebagai berikut:

$$
\text { IKM }=\frac{\text { Total dari nilai persepsi pada layanan }}{\text { Total layanan yang Terisi }} \mathrm{X} \text { nilai penimbang }
$$

Untuk memudahkan interpretasi terhadap penilaian IKM yaitu antara 25-100 maka hasil penilaian tersebut diatas dikonversikan dengan nilai dasar 25 , dengan rumus sebagai berikut:

\section{Index Kepuasan Masyarakat X 25}

Mengingat unit pelayanan dianggap relevan, (2) Memberikan bobot mempunyai karakteristik yang berbedayang berbeda terhadap unsur yang beda, maka setiap layanan dimungkinkan dominan dalam unit layanan, dengan untuk (1) Menambah unsur yang catatan jumlah bobot seluruh unsur tetap.

Tabel 3.1

Nilai Persepsi, Interval IKK, Interval Konversi IKK, Mutu Layanan dan Kinerja Layanan

\begin{tabular}{|c|c|c|c|c|}
\hline Nilai Persepsi & $\begin{array}{c}\text { Nilai } \\
\text { Interval } \\
\text { IKM }\end{array}$ & $\begin{array}{c}\text { Nilai Interval } \\
\text { Konversi IKM }\end{array}$ & $\begin{array}{c}\text { Mutu } \\
\text { Pelayanan }\end{array}$ & $\begin{array}{c}\text { Kinerja Unit } \\
\text { Pelayanan }\end{array}$ \\
\hline 1 & $1,00-1,75$ & $25-43,75$ & $\mathrm{D}$ & Tidak baik \\
\hline 2 & $1,76-2,50$ & $43,76-62,50$ & $\mathrm{C}$ & Kurang baik \\
\hline 3 & $2,51-3,25$ & $62,51-81,25$ & $\mathrm{~B}$ & Baik \\
\hline 4 & $3,26-4,00$ & $81,26-100,00$ & $\mathrm{~A}$ & Sangat baik \\
\hline
\end{tabular}


Hasil perhitungan dan penggunaan rumus kemudian dimasukan ke dalam diagram kartesius. Dari sini, diketahui mana indicator-indikator yang merupakan perstasi dan yang perlu dipertahankan.

\begin{tabular}{|c|c|c|}
\cline { 2 - 3 } Kepentingan & $\begin{array}{c}\text { Kuadran A } \\
\text { Prioritas } \\
\text { Utama }\end{array}$ & $\begin{array}{c}\text { Kuadran B } \\
\text { Pertahankan } \\
\text { Prestasi }\end{array}$ \\
Kinerja & $\begin{array}{c}\text { Kuadran C } \\
\text { Prioritas } \\
\text { Rendah }\end{array}$ & Kuadran D \\
& Berlebihan \\
\hline
\end{tabular}

\section{Keterangan:}

1. Kuadran A menunjukan aspek atau atribut yang dianggap mempengaruhi kepuasan masyarakat, termasuk unsur-unsur jasa yang dianggap sangat penting, tetapi manajemen belum melaksanakannya sesuai keinginan masyarakat pengguna jasa.

2. Kuadran B menunjukkan unsur jasa pokok yang telah berhasil dilaksanakan organisasi/instansi dan untuk itu wajib dipertahankan.
Selain itu dapat juga diketahui indikatorindikator mana yang kualitasnya tidak bagus dan perlu mendapat prioritas untuk ditingkatkan.
Dianggap sangat penting dan sangat memuaskan.

3. Kuadran $\mathrm{C}$ menunjukkan beberapa aspek yang kurang penting pengaruhnya bagi masyarakat. Pelaksanaannya oleh organisasi biasa-biasa saja. Dianggap kurang penting dan kurang memuaskan.

4. Kuadran D menunjukkan aspek yang mempengaruhi pelanggan kurang penting, tetapi pelaksanaannya berlebihan. Dianggap kurang penting tetapi sangat memuaskan. 


\section{PEMBAHASAN}

Hasil Penelitian kepuasan pelayan pada Dinas Kpendudukan dan Catatan Sipil Kabupaten Cirebon didasarkan pada indicator yang ada di dalam Indeks Kepuasan Masyarakat (IKM) berdasarkan pada Keputrusan Menteri Negara Pendayagunaan aparatur Negara Nomor Kep/25/M.PAN/2/2004 tentang pedoman Umum Penyusunan Indeks Kepuasan Masyarakat. Dalam keputusan Menpan tersebut terdapat 14 indikator untuk

Berdasarkan hasil penelitian yang telah dilakukan Nilai persepsi, Interval IKM， Interval Konversi IKK, Mutu layanan dan Kinerja Dinas Pelayanan menukur Kepuasan Masyarakat yaitu: prosedur pelayanan, peryaratan pelayanan, kejelasan petugas pelayanan, kedidiplinan petugas pelayanan, tanggungjawab petugas pelayanan, kemmampuan petugas pelayanan, kecepatan pelayanan, keadilan dalam mendapatkan pelayanan, kesopanan dan keramahan petugas, kewajaran biaya pelayanan, kepastian biaya pelayanan, kepastian jadwal pelayanan, kenyamanan lingkungan, dan keamanan pelayanan.

Kependudukan dan Pencatatan Sipil Kabupaten Cirebon dapat dilihat dalam tabel berikut:

Tabel 4.1

Kepuasan Masyarakat

\begin{tabular}{|c|c|c|c|c|}
\hline $\begin{array}{c}\text { Nilai } \\
\text { Persepsi }\end{array}$ & $\begin{array}{c}\text { Nilai Interval } \\
\text { IKM }\end{array}$ & $\begin{array}{c}\text { Nilai Interval } \\
\text { Konversi IKM }\end{array}$ & Mutu Pelayanan & Keterangan \\
\hline 2,98 & $2,51-3,25$ & 74,30 & B & Baik \\
\hline
\end{tabular}

Berdasarkan tabel 5.17 pada nilai persepsi, interval IKM, interval konversi IKK, mutu layanan dan kinerja layanan, didapatkan nilai interval konversi IKM yaitu 74,30 artinya mutu pelayanan mempunyai nilai $B$, yaitu baik. Berdasarkan rumus nilai Indeks Kepuasan Masyarakat (IKM) dan
Kepmen PAN No.25 tahun 2004 yang dihitung dengan menggunakan nilai ratarata tertimbang masing-masing unsur pelayanan. Dalam penghitungan IKM terdapat 14 unsur atau indikator yang dikaji, maka dapat diketahui dengan nilai indeks sebesar 2,98. 
Tabel 4.2

Rekapan Indeks Kepuasan Masyarakat dalam Pelayanan Publik

di Disdukcapil Kabupaten Cirebon

\begin{tabular}{|c|c|c|c|c|c|c|c|}
\hline \multirow[t]{2}{*}{ No } & \multirow[t]{2}{*}{ PELAYANAN } & \multicolumn{2}{|c|}{ Nilai skor } & \multirow{2}{*}{$\begin{array}{c}\text { X } \\
\text { Bar }\end{array}$} & \multirow{2}{*}{$\begin{array}{l}\text { Kate } \\
\text { gori }\end{array}$} & \multirow{2}{*}{$\begin{array}{c}\text { Y } \\
\text { Bar }\end{array}$} & \multirow{2}{*}{$\begin{array}{c}\text { Tki } \\
\%\end{array}$} \\
\hline & & Kinerja & Kepentingan & & & & \\
\hline 1 & Prosedur & 471 & 478 & 3,14 & B & 3,19 & 98,54 \\
\hline 2 & Persyaratan & 471 & 505 & 3,14 & B & 3,37 & 93,27 \\
\hline 3 & Kejelasan & 447 & 411 & 2,98 & $\mathrm{~B}$ & 2,74 & 108,76 \\
\hline 4 & Kedisiplinan Petugas & 387 & 501 & 2,58 & B & 3,34 & 77,25 \\
\hline 5 & Tanggung jawab Petugas & 419 & 427 & 2,79 & $\mathrm{~B}$ & 2,85 & 98,13 \\
\hline 6 & Kemampuan Petugas & 512 & 491 & 3,41 & A & 3,27 & 104,28 \\
\hline 7 & Kecepatan & 429 & 464 & 2,86 & B & 3,09 & 92,46 \\
\hline 8 & Keadilan & 476 & 502 & 3,17 & $\mathrm{~B}$ & 3,35 & 94,82 \\
\hline 9 & Kesopanan Petugas & 427 & 502 & 2,85 & B & 3,35 & 85,06 \\
\hline 10 & Kewajaran & 511 & 475 & 3,41 & A & 3,17 & 107,58 \\
\hline 11 & Kepastian jadwal & 293 & 298 & 3,22 & B & 1,99 & 98,32 \\
\hline 12 & Kepastian biaya & 433 & 466 & 2,87 & B & 3,11 & 92,92 \\
\hline 13 & Kenyamanan & 361 & 515 & 2,41 & $\mathrm{C}$ & 3,43 & 70,09 \\
\hline 14 & Keamanan lingkungan & 454 & 503 & 3,03 & B & 3,35 & 90,26 \\
\hline & Nilai rata-rata & 435,071 & 467 & 2,98 & B & 3,11 & 93,7 \\
\hline
\end{tabular}

Selanjutnya hasil perhitunganh tersebut dimasukkan ke dalam Diagram Kartesius seperti dalam diagram berikut ini:

\section{Keterangan:}

1. Kuadran A menunjukkan aspek yang dianggap mempengaruhi kepuasan masyarakat yang dikategorikan jasa yang dianggap sangat penting akan tetapi belum dilaksanakan oleh organisasi. Aspek ini menyankut indicator: a) Kedisplinan, b) kesopanan dan keramahan, c) kenyamanan lingkungan. Aspek ini merupakan aspek yang membutuhkan prioritas. 
2. Kuadran B merupakan aspek yang telah dilaksanakan oleh organisasi oleh karena itu harus dipertahankan. Aspek terdapat enam indicator yaitu: a) Prosedur pelayanan, b) persyaratan pelayanan, c) kemampuan petugas pelayanan, d) keadilan dalam pelayanan, e) kewajaran biaya, dan f) keamanan pelayanan.

3. Kuadran $\mathrm{C}$ adalah aspek yang kurang penting pengaruhnya dan masyarakat disamping itui pelaksanaannya oleh organisasi biasa saja, artinya merupakan aspek yang

\section{SIMPULAN}

Bedasarkan hasil penelitian yang telah dijelaskan diatas, maka dapat dikemukakan kesimpulan sebagai berikut:

1. Berdasarkan hasil penelitan tentang Indeks Kepuasan Masyarakat dalam Pelayanan Publik pada Dinas Kependudukan dan Catatan Sipil Kabupaten Cirebon dengan menggunakan Kepuasan Masyarakat (IKM) sesuai dengan Keputusan Menteri Pendayagunaan Aparatur Negara No. 25 tahun 2004 maka nilai interval konversi Indeks Kepuasan dianggap kurang penting dan kurang memuaskan. Aspek ini meliputi indicator: a) tanggung jawab petugas, b) kecepatan pelayanan, c) kepastian jadwal pelayanan dan biaya pelayanan.

4. Kuadran D menunjukkan aspek yang dianggap oleh masyarakat kurang penting, aspek ini dilaksanakan secara berlebihan, tetapi menunjukan hasil yang sangat memuaskan. Aspek ini terdiri dari dua indikator: a) kejelasan petugas pelayanan, dan b) kepastian biaya pelayanan.

Masyarakat (IKM) sebesar 74, 30 dengan nilai persepsi 29, 8 dengan mutu pelayanan dikategorikan $\mathrm{B}$ dan kinerja unit pelayanan yang baik.

2. Berdasarkan hasil penjabaran diagram kartesius maka indicator pelayanan yang harus diprioritaskan adalah: kedisplinan, kesopanan dan keramahan petugas, serta kenyamanan lingkungan.

\section{DAFTAR PUSTAKA}

Arikunto, Suharsimi. 2006. Prosedur Peneltian Suatu Pendekatan Praktek. Jakarta. Rineka Cipta 
Didukcapil Kemndagri. 2014. Tertib Administrasi Kependudukan. www.dukcapil.go.id. diunduh 10 Mei 2017

Goetsch, D.L \& Davis, S. 1994. Introduction to Total Quality, Quality, Productivity, Competitiveness, Englewood Cliffs, NJ: Prentice Hall International Inc

Kotler, P. 2004. Manajemen Pemasaran, Edisi Millenium. Jakarta: Penerbit PT. Prenhallinda

Perpres No.25 Tahun 2008 tentang Tata Cara dan Persyaratan Pendaftaran Penduduk dan Pencatatan Sipil

Tjiptono, F. 2000. Perspektif Manajemen dan Pemasaran. Kontemporer. Yogya karta: Penerbit Andi
. 2002. Prinsip-prinsip Total Quality Service.Yogyakarta: Penerbit Andi . 2005. Pemasaran Jasa. Malang: Bayumedia Publising . 2012. Service Manajemen, Mewujudkan Layanan Prima.Yogyakarta: CV Andi Offset 